Linear Microelectronic Systems 
Other titles in Electrical and Electronic Engineering

B. A. Gregory: An Introduction to Electrical Instrumentation Paul A. Lynn: An Introduction to the Analysis and Processing of Signals

A. Potton: An Introduction to Digital Logic

G. Williams: An Introduction to Electrical Circuit Theory 


\title{
Linear Microelectronic Systems
}

\author{
A. G. Martin \\ and \\ F. W. Stephenson \\ Lecturers in Electronic Engineering \\ The University of Hull
}

Macmillan Education 
๑ A. G. Martin and F. W. Stephenson 1973

All rights reserved. No part of this publication may be reproduced or transmitted, in any form or by any means, without permission.

First published 1973 by

THE MACMILLAN PRESS LTD

London and Basingstoke

Associated companies in New York Dublin

Melbourne Johannesburg and Madras

ISBN 978-0-333-14380-3 ISBN 978-1-349-86175-0 (eBook)

DOI 10.1007/978-1-349-86175-0

The paperback edition of this book is sold subject to the condition that it shall not, by way of trade or otherwise, be lent, resold, hired out, or otherwise circulated without the publisher's prior consent, in any form of binding or cover other than that in which it is published and without a similar condition including this condition being imposed on the subsequent purchaser. 


\section{Contents}

1 ANALYTICAL TECHNIQUES 1

1.1 Linear circuit elements 1

1.2 Loop equations $\quad 2$

1.3 Node equations 3

1.4 Sources, equivalent sources and transforms 4

1.5 Two-ports 6

1.6 Interconnection of two-ports 9

1.7 Network solution by Cramer's rule 11

1.8 Gaussian elimination for network solution 12

1.9 Roots of polynomials 13

$\begin{array}{lr}\text { References } & 15\end{array}$

$\begin{array}{lr}\text { Problems } & 15\end{array}$

2 TRANSFER FUNCTIONS 17

$\begin{array}{ll}2.1 \text { Complex frequency } & 17\end{array}$

$\begin{array}{ll}2.2 & \text { Network functions } \\ 2.3 & 19\end{array}$

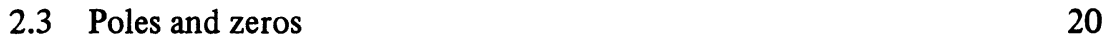

2.4 Evaluation of network functions 21

2.5 ' First-order response 31

Summary $\quad 34$

$\begin{array}{ll}\text { Problems } & 35\end{array}$

3 ACTIVE DEVICES AND CIRCUIT MODELS 37

$\begin{array}{lll}3.1 & \text { Two-port active networks } & 37\end{array}$

3.2 Circuit modelling $\quad 40$

3.3 Ideal amplifiers 43

3.4 Three-terminal control valves $\quad 45$

3.5 The bipolar junction transistor 46

3.6 The field effect transistor 49

$\begin{array}{lll}3.7 & \text { Bias circuits } & 51\end{array}$

3.8 Common emitter and common source amplifiers $\quad 54$

3.9 Common collector and common drain amplifiers 56

3.10 Common base and common gate amplifiers 58

$\begin{array}{lr}3.11 \text { High frequency equivalent circuits } & 59\end{array}$



$\begin{array}{ll}3.13 \text { Steady state responses } & 64\end{array}$

$\begin{array}{ll}\text { Summary } & 65\end{array}$

References $\quad 66$

$\begin{array}{lc}\text { Problems } & 66\end{array}$ 
4 AMPLIFIER CIRCUITS

4.1 Constant current sources $\quad 70$

4.2 Current generator circuits $\quad 70$

4.3 Constant current loads 73

4.4 Direct coupling and drift $\quad 74$

4.5 The differential amplifier 75

4.6 Incremental analysis of differential and common mode operation $\quad 76$

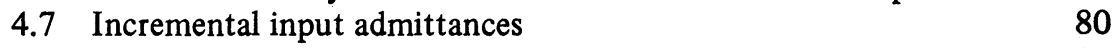

4.8 Single input, single output 81

4.9 Two inputs, differing source resistances 81

4.10 Difference output $\quad 82$

4.11 Differential amplifier-d.c. bias and offsets 83

4.12 Differential amplifier-current generator loads $\quad 85$

4.13 Composite transistors $\quad 88$

4.14 D.C. coupling $\quad 90$

4.15 Single-ended output circuitry 91

4.16 Output protection 98

4.17 Paraphase output $\quad 99$

4.18 The integrated operational amplifier $\quad 100$

Summary 103

References 103

$\begin{array}{ll}\text { Problems } & 104\end{array}$

5 NEGATIVE FEEDBACK 107

5.1 General model for negative feedback 107

5.2 Idealised feedback connections 108

5.3 Impedance calculations for idealised feedback networks $\quad 110$

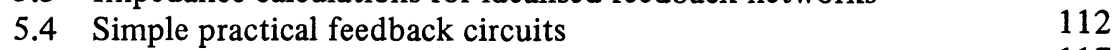

5.5 Further properties of negative feedback 117

5.6 Negative feedback and the operational amplifier $\quad 122$

$\begin{array}{ll}5.7 \text { Basic analogue computing circuits } & 127\end{array}$

5.8 Negative feedback and the differential input amplifier $\quad 131$

Summary 133

References 134

Problems 134

6 POSITIVE FEEDBACK AND FREQUENCY RESPONSE 135

6.1 The Wien bridge oscillator 135

6.2 Amplitude limiting by nonlinearities 137

6.3 The Nyquist criterion 139

6.4 Phase shift oscillators 141

6.5 LC oscillators 142

6.6 Oscillators-final considerations 143

6.7 Stability of negative feedback amplifiers 144

6.8 One- and two-pole amplifiers 145

6.9 Third and higher order feedback amplifiers 146

6.10 Lag compensation $\quad 147$

6.11 Lead compensation $\quad 150$

6.12 Poles, zeros and time functions 151 
6.13 One- and two-pole low-pass amplifiers-step input 152

6.14 Square wave response of a band-pass amplifier 155

Summary

References

Problems

7 NODAL ANALYSIS OF AMPLIFIER CIRCUITS 159

7.1 Indefinite nodal admittance matrix (INAM) 159

$\begin{array}{ll}7.2 \text { Definite nodal admittance matrix (NAM) } & 161\end{array}$

$\begin{array}{ll}7.3 \text { Obtaining network functions I } & 162\end{array}$

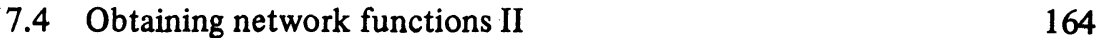

$\begin{array}{lll}7.5 & \text { Amplifier equivalent circuits } & 168\end{array}$

7.6 Evaluation of the voltage transfer function for an active network 170

$\begin{array}{lll}7.7 & \text { Network matrices } & 172\end{array}$

$\begin{array}{lr}\text { Summary } & 177\end{array}$

$\begin{array}{lr}\text { References } & 178\end{array}$

$\begin{array}{ll}\text { Problems } & 178\end{array}$

8 THE AMPLIFIER AS A NETWORK ELEMENT 182

$\begin{array}{ll}\text { 8.1 Programming an analogue computer } & 182\end{array}$

8.2 Analysis of analogue computer networks 185

$\begin{array}{ll}8.3 \text { Electrical filters } & 190\end{array}$

8.4 Active filters using operational amplifiers 194

$\begin{array}{ll}\text { 8.5 Active filters using controlled sources } & 196\end{array}$

$\begin{array}{ll}8.6 \text { The gyrator } & 201\end{array}$

$\begin{array}{ll}\text { Summary } & 203\end{array}$

References $\quad 203$

$\begin{array}{ll}\text { Problems } & 203\end{array}$

9 THE AMPLIFIER IN PRACTICE 205

$\begin{array}{lll}9.1 \text { Bias currents } & 205\end{array}$

9.2 Offsets, drift and equivalent circuit 206

9.3 Latch-up and input breakdown 208

$\begin{array}{ll}9.4 \text { Power supplies } & 209\end{array}$

$\begin{array}{ll}9.5 & \text { Additional frequency compensation } \\ 9.6 & 210\end{array}$

$\begin{array}{ll}\text { 9.6 Review of operational amplifiers } & 210\end{array}$

$\begin{array}{ll}9.7 & \text { FET input integrated circuits } \\ 9.8 & 212\end{array}$

9.8 Chopper and chopper stabilised amplifiers 212

$\begin{array}{ll}9.9 \text { Integrators } & 213\end{array}$

$\begin{array}{ll}9.10 \text { Differentiators } & 216\end{array}$

$\begin{array}{ll}9.11 \text { Some linear applications } & 219\end{array}$

9.12 Some nonlinear applications $\quad 222$

$\begin{array}{ll}\text { References } & 231\end{array}$

Appendix 1 DETERMINANTS AND MATRICES 232

Appendix 2 SIGNAL FLOW GRAPHS 234

GLOSSARY OF OPERATIONAL AMPLIFIER TERMINOLOGY 237

$\begin{array}{ll}\text { INDEX } & 239\end{array}$ 


\section{Preface}

The continually developing field of electronics requires a constant effort on the part of the teacher to optimise.his selection from what is a vast range of topics. Somewhat in contrast, the student engineer has not only to know more about circuit techniques, amplifiers, passive networks, but also how the parts fit together to make a system and to be more adept at circuit analysis than ever before. Considering the notion that the electronic engineer constructs a system, probably by adding passive components to interconnect or modify the function of integrated circuit modules, we have tried to present such concepts and analytical techniques as he is likely to require before his creative purpose can develop.

We have collected the material for this book whilst teaching courses in circuit theory, electronics and control systems at the University of Hull. The reader will probably notice that the approach varies from formal argument to heuristic presentation of topics. Our aim has been to consider each aspect in the way most easily appreciated by the student rather than to preserve an unwieldy formality.

It has, unfortunately, been necessary to omit a certain amount of useful material. Particularly, we have avoided considering the technology of circuit integration. The construction of transistors, layout of components on the silicon chip, and trade-offs in the circuit arrangement are part of a fascinating craft that we omitted so that the text could be kept to its limited size. Neither is there much consideration of design methods in the formal sense. We hope the reader will be stimulated to follow up the references given or other suitable sources where our coverage is limited.

One feature, which we hope is evident, is that in analysing a system a mixture of inspiration, mathematical analysis and astute computing is required. To this end, computational and analytical techniques are stressed, though the reader will have to supply his own inspiration.

Chapter 1 contains analytical and computing material for use in later chapters. The concept of frequency response is introduced by means of elementary circuits in chapter 2. This leads to the ideas of complex frequency and transfer functions. These ideas are applied to simple circuits in chapter 3 where we try to stress the similarity between circuit arrangements while introducing the analysis technique of circuit modelling. In chapter 4 the elements of an amplifier are considered. We have kept in mind the differential input single ended output, voltage amplifier most often found in integrated devices. Chapter 5 goes on to consider negative feedback by which the amplifier is controlled. Negative feedback also allows the versatile use of the circuit as a functional block. Intrinsically connected with feedback is the question of stability, dealt with in chapter 6 , because it is either wanted for a functional circuit or not, as in the case of an oscillator. It seems appropriate at this point to draw together the ideas variously touched on by a formal exposition of analytical methods in chapter 7 . These methods are applied to larger networks in 
chapter 8 . Here, the use of a systems approach is exemplified by its application to analogue circuitry and to active filters. Chapter 9 is mainly concerned with practical problems in the use of integrated devices and with some applications. Material that the reader may need at various points in the text is collected in the appendixes. The first contains matrix algebra, the second signal flow analysis and the third a short glossary of integrated circuit terminology.

We would like to acknowledge the stimulation provided by our colleagues and students. Particular thanks are due to Mrs E. M. Bowen, who, with extreme patience, performed the arduous task of typing.

Hull, Yorkshire

A. G. Martin

F. W. Stephenson 